\title{
Identification of a non-native Cynoscion species (Perciformes: Sciaenidae) from the Gulf of Cádiz (southwestern Spain) and data on its current status
}

\author{
Rafael Bañón ${ }^{1,2}$, Alberto Arias ${ }^{3}$, Diego Arana ${ }^{4}$, Jose A. Cuesta ${ }^{3}$ \\ ${ }^{1}$ Instituto de Investigaciones Marinas, CSIC, c/ Eduardo Cabello 6, 36208 Vigo, Pontevedra, Spain. \\ (RB) (Corresponding author) E-mail: anoplogaster@yahoo.es. ORCID-iD: http://orcid.org/0000-0001-6038-9335 \\ ${ }^{2}$ Grupo de Estudos do Medio Mariño (GEMM), Puerto deportivo s/n, 15960 Ribeira, A Coruña, Spain. \\ ${ }^{3}$ Instituto de Ciencias Marinas de Andalucía, CSIC, Avenida República Saharaui 2, 11519 Puerto Real, Cádiz, Spain. \\ (AA) E-mail: alberto.arias@icman.csic.es. ORCID-iD: http://orcid.org/0000-0002-5883-3078; \\ (JAC) E-mail: jose.cuesta@icman.csic.es. ORCID-iD: http://orcid.org/0000-0001-9482-2336 \\ ${ }^{4}$ Agencia de Gestión Agraria y Pesquera de Andalucía, c/ Bergantín 39, 41012 Sevilla, Spain. \\ (DA) E-mail: diego.aranam@gmail.com. ORCID-iD: http://orcid.org/0000-0001-6638-4105
}

\begin{abstract}
Summary: Cynoscion is a genus of fish in the family Sciaenidae from the Atlantic and Pacific American coasts that is important in recreational and commercial fisheries. Morphological analysis identifies a species inhabiting the Gulf of Cádiz (southern Spain) as the weakfish, Cynoscion regalis, a native of the northwest Atlantic. This finding is also confirmed by molecular identification using 16S and Cox1genes. Based on the examination of a previous manuscript, the assignation of this species to the spotted seatrout, Cynoscion nebulosus, is considered a misidentification. C. regalis has been reported in the area since 2011 and is now considered an established species that is distributed along the Guadalquivir River estuary and is a target of local artisanal fisheries. The pathway of introduction is unknown, but possible mechanisms are considered, of which ballast water seems to be the most plausible. A revision of non-native sciaenids also found in European waters is carried out. The ecological impact of weakfish on the local fish community is still unknown and should be object of future studies.
\end{abstract}

Keywords: biological invasion; marine introduction; weakfish; Cynoscion regalis; Guadalquivir estuary; taxonomy.

Identificación de una especie no nativa de Cynoscion (Perciformes: Sciaenidae) en el Golfo de Cádiz (suroeste de España) y datos sobre su estado actual

Resumen: Cynoscion es un género de peces de la familia Sciaenidae, de importancia en la pesca deportiva y comercial, que habita las costas americanas del Atlántico y el Pacífico. Una especie que habita en el Golfo de Cádiz (suroeste de España) fue identificada mediante análisis morfológico como corvinata real Cynoscion regalis, nativa del Atlántico Noroeste. La identificación también fue confirmada por análisis molecular, utilizando los genes 16S y Cox1. Basándose en el examen de una publicación anterior, la asignación de esta especie a corvinata pintada Cynoscion nebulosus se considera un error de identificación. Existen registros de C. regalis en esta zona desde 2011 y ahora se considera una especie establecida, distribuida a lo largo del estuario del río Guadalquivir y objeto de la pesca artesanal local. La vía de introducción es desconocida, pero se consideran los posibles mecanismos de introducción, de los cuales el agua de lastre parece ser el más probable. Se realizó una revisión de los esciaénidos no nativos en aguas europeas. Aún se desconoce el impacto ecológico de la corvinata real en la comunidad local de peces, que debe ser objeto de futuros estudios.

Palabras clave: invasión biológica; introducción de especies marinas; corvinata real; Cynoscion regalis; estuario del Guadalquivir; taxonomía.

Citation/Como citar este artículo: Bañón R., Arias A., Arana D., Cuesta J.A. 2017. Identification of a non-native Cynoscion species (Perciformes: Sciaenidae) from the Gulf of Cádiz (southern Spain) and data on its current status. Sci. Mar. 81(1): 19-26. doi: http://dx.doi.org/10.3989/scimar.04494.21A

Editor: A. García-Rubies.

Received: June 20, 2016. Accepted: November 4, 2016. Published: January 18, 2017.

Copyright: (C) 2017 CSIC. This is an open-access article distributed under the terms of the Creative Commons Attribution (CC-by) Spain 3.0 License. 


\section{INTRODUCTION}

The family Sciaenidae comprises approximately 70 genera and 270 species of demersal fishes that are commonly known as drums and croakers, found mainly over muddy or sandy bottoms of tropical, subtropical and warm temperate regions of the Atlantic, Indian and $\mathrm{Pa}$ cific oceans, from the shoreline up to about $600 \mathrm{~m}$ depth (McEachran and Fechhelm 2005, Nelson 2006). Most species are marine, a few are euryhaline and support a wide range of salinities, and 25 species, mostly from South America, are strictly freshwater (Casatti 2002).

The eastern Atlantic, with 19 sciaenid species, is the least diverse geographical area, compared to the eastern Pacific, with 82 species, the western Atlantic, with 82, and the Indo-West Pacific, with 92 (Lo et al. 2015). Only five native species occur in Iberian and Atlantic European waters: Argyrosomus regius (Asso, 1801), Sciaena umbra Linnaeus, 1758, Umbrina canariensis Valenciennes, 1843, Umbrina cirrosa (Linnaeus, 1758) and Umbrina ronchus Valenciennes, 1843 (Quéro et al. 2003, Lloris 2015).

Two introduced sciaenids species have also been reported in Atlantic European waters. Two living specimens of the Atlantic croaker, Micropogonias undulatus (Linnaeus, 1766), were reported in Belgian waters in 1998 and 2001 (Stevens et al. 2004) and one fresh specimen of about $28 \mathrm{~cm}$ total length, tentatively identified as $M$. undulatus, which was found displayed for sale at Plymouth Fish Market in September 2011 (http://www.glaucus.org.uk/), was probably captured in the southwestern approaches (SW Cornwall). One specimen of the spotted seatrout, Cynoscion nebulosus (Cuvier, 1830), was caught in 2011 by a fishing vessel on a sandy bottom near the Guadalquivir River estuary, southern Spain (Acosta et al. 2013).

The genus Cynoscion Gill, 1861 is a large, ecologically and economically important genus of marine fishes in the family Sciaenidae that is found throughout tropical and subtropical coastal waters of the New World (Vergara-Chen 2009). Currently, there are 24 recognized species, 12 from the eastern Pacific and 12 from the western Atlantic, inhabiting estuarine and inshore waters, mainly in the tropical and subtropical regions of Central and South America (Chao 2002a).

The Gulf of Cádiz is the sub-basin of the North Atlantic nearest to the Strait of Gibraltar. It is bordered to the north by the southwest coasts of the Iberian Peninsula, to the south by the Atlantic coast of Morocco, to the east by the Strait of Gibraltar, and to the west by the $9^{\circ} \mathrm{W}$ meridian (Criado-Aldeanueva et al. 2006). There is an important artisanal fishery and shellfishing sector in the area, with a fleet composed of about 1000 vessels that capture more than 50 commercial species (Silva et al. 2002), although current official data reduce the number of vessels by nearly half. Human impacts on this marine ecosystem through exploitation of marine resources, fishing and the invasion of non-indigenous species have also been reported (Chicharo et al. 2009).

There are three general mechanisms through which non-native species may enter a new region: importation as or with a commodity, arrival through a transport vector and dispersal by the species themselves, either along infrastructure corridors (e.g. roads, canals) or unaided (Hulme et al. 2008). For fishes, the most widely reported pathways of introduction are ballast water transport, marine culture, aquarium trade, oil drilling platform transfer, fisheries development, species released for scientific research, and movement through canals (Liao et al. 2010).

Molecular techniques have been successfully integrated with traditional morphological analysis in the identification of fishes, reinforcing the resulting taxonomic identification and reducing the possibility of identification mistakes (Bañón et al. 2013). In addition, the use of DNA barcodes efficiently helps to detect and understand marine invasions through the identification of exotic species and their geographic origin (Bariche et al. 2015).

The present work discusses the current taxonomic status of the Cynoscion species found in the Gulf of Cádiz based on morphological and molecular features within an integrative context. The distribution, abundance, possible mechanisms of introduction and ecological consequences of this introduced species are also discussed.

\section{MATERIALS AND METHODS}

\section{Sampling, morphological identification and study area}

Thirteen specimens were caught with gillnets by local fishermen in the Gulf of Cádiz (SW Spain). The specimens were initially preserved frozen at $-20^{\circ} \mathrm{C}$. After thawing them, we took measurements and meristic characters to the nearest $\mathrm{mm}$ and then preserved them in ethanol $(80 \%)$ in the laboratory. The identification was made using descriptions and keys reported by Chao $(2002 \mathrm{a}, \mathrm{b})$. The preserved specimens were deposited at the Colección de Fauna Marina del Centro Oceanográfico de Málaga, with the reference numbers CFM-IEOMA-6020 to 6032.

\section{Molecular identification}

DNA barcode sequences were obtained for 3 out of the 13 specimens of Cynoscion collected in this study (CFM-IEOMA 6020-6022). The molecular identification was based on partial sequences of the mitochondrial genes 16S RNA and Cytochrome c oxidase subunit I (Cox1). Total genomic DNA was extracted from fin tissue following a modified Chelex $10 \%$ protocol by Estoup et al. (1996).

Target mitochondrial DNA from the $16 \mathrm{~S}$ rRNA and Cox 1 genes was amplified with polymerase chain reaction (PCR) using the following cycling conditions: 2 min at $95^{\circ} \mathrm{C}, 40$ cycles of $20 \mathrm{~s}$ at $95^{\circ} \mathrm{C}, 20 \mathrm{~s}$ at 45 $48^{\circ} \mathrm{C}, 45 \mathrm{~s}(16 \mathrm{~S})$ or $47 \mathrm{~s}(\mathrm{Cox} 1)$ at $72^{\circ} \mathrm{C}$, and $5 \mathrm{~min}$ at $72^{\circ} \mathrm{C}$. Primers $1472\left(5^{\prime}-\mathrm{AGA}\right.$ TAG AAA CCA ACC TGG -3') (Crandall and Fitzpatrick 1996) and 16L2 (5'TGC CTG TTT ATC AAA AAC AT-3') (Schubart et al. 2002) were used to amplify $611 \mathrm{bp}$ of $16 \mathrm{~S}$, while primers COH6 (5'- TAD ACT TCD GGR TGD CCA AAR AAY CA -3') and COL6b (5'- ACA AAT CAT 

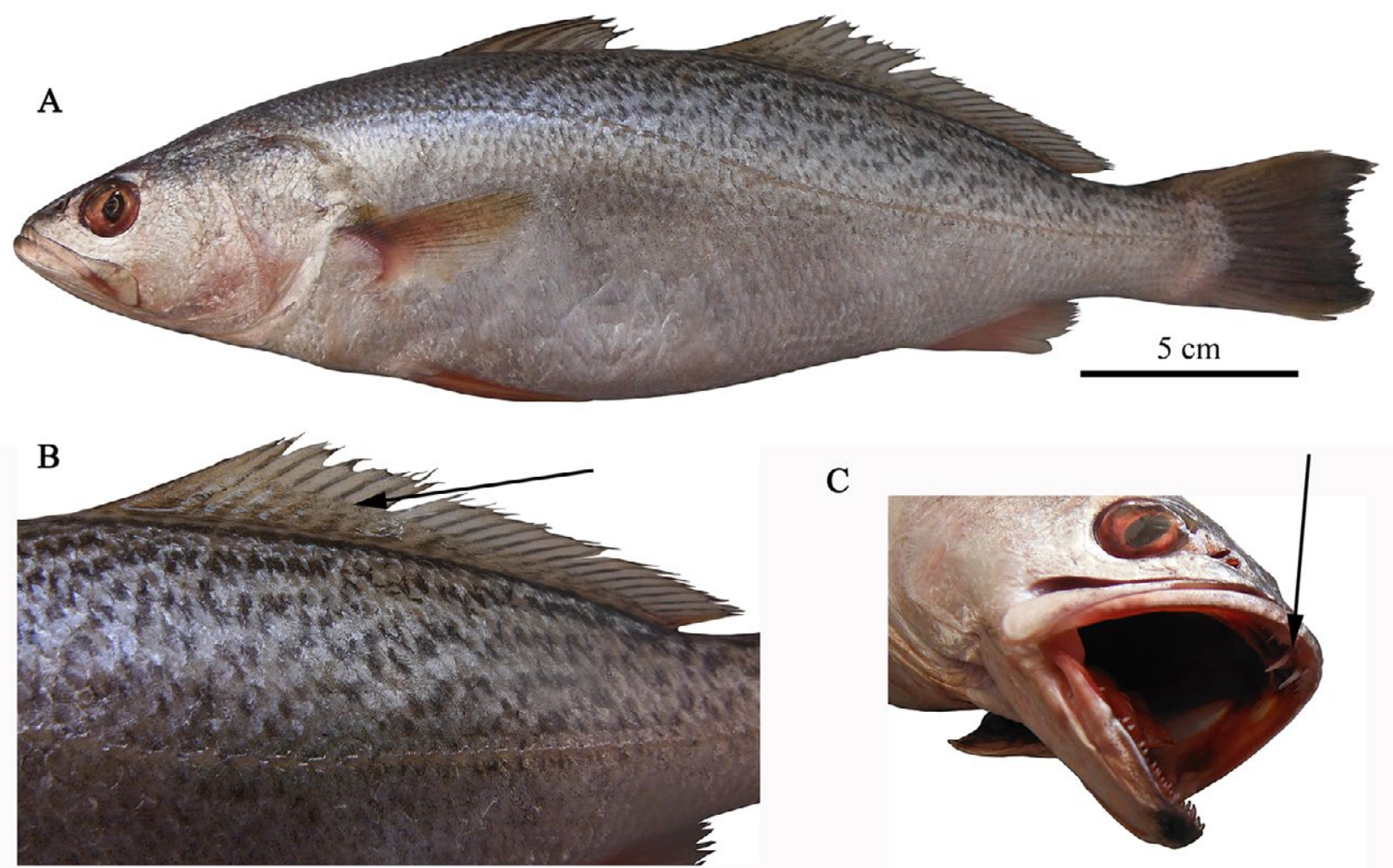

C

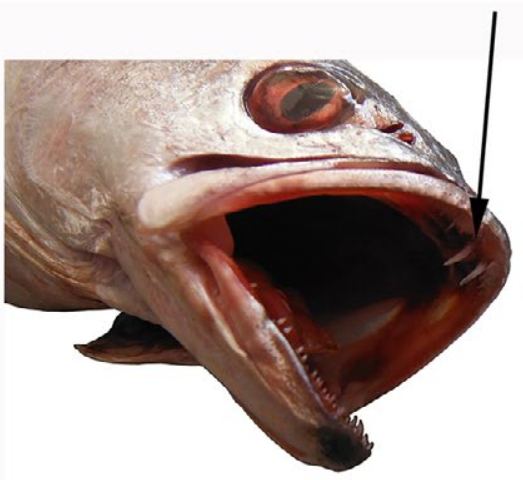

Fig. 1. - Specimen of C. regalis. A, view of an entire specimen of $313 \mathrm{~mm}$ TL; B, detail of scales at the base of soft dorsal fin; C, detail of the two large canine-like teeth in the upper jaw. The arrows indicate the position of the described character.

AAA GAT ATY GG -3') (Schubart and Huber 2006) were used to amplify $660 \mathrm{bp}$ of Cox 1 . PCR products were sent to Stab-Vida Laboratories to be purified and then bidirectionally sequenced. Sequences were edited using the Chromas software, version 2.0. The final DNA sequences obtained were used in a BLAST search executed on the NCBI webpage to get the sequence that matched best.

An evolutionary distances analysis was carried out in MEGA6 (Tamura et al. 2013). Alignment of 16S and Cox 1 sequences was carried out using sequences obtained from the specimens studied as well as other congeneric species downloaded from GenBank (http:// www.ncbi.nlm.nih.gov). The phylogeny reconstruction analyses were inferred from neighbour-joining using the p-distance method. The nodal confidence of obtained topologies was assessed via 2000 bootstrap replicates.

\section{Fishery data}

Catch data were compiled from fishing statistics provided by the Andalusian fisheries authorities and calculated using the sales notes submitted by fish market operators where weakfish was landed and sold. Distribution of $C$. regalis in the Gulf of Cádiz was estimated on landings as well as on-field work carried out at the ports to confirm the presence of weakfish among catches. Skippers from vessels landing weakfish were interviewed in order to obtain more accurate information on where the weakfish was being caught.

\section{RESULTS}

\section{Material examined}

Cynoscion regalis (Bloch and Schneider, 1801) (Fig. 1), 13 specimens between 276 and $330 \mathrm{~mm}$ total length (TL), 234 and $285 \mathrm{~mm}$ standard length (SL), 22 February 2016, vessel "Dolores y Juan”, 36²9.736' N 6³2.922' W, 17-18 m depth.

\section{Description}

Body elongated and moderately compressed, body depth 3.5-4.1 times the SL; predorsal profile nearly straight and ventral concave; head moderate and conical, 3.4-3.7 times the SL; snout pointed with lower jaw projecting; maxillary reaching beyond pupil; upper jaw with a pair of large canine-like teeth at its tip; interorbital width greater than horizontal eye diameter; one continuous and long dorsal fin with a deep notch between spinous and soft-rayed portion; anal fin shorter and placed at the back of the body; scales at the base of soft dorsal and anal fins; gas bladder with a pair of nearly straight, horn-like appendages. Colouration: body silvery, darker above and lighter below; back with small spots forming undulating dotted lines. Pelvic and anal fins are yellowish, while the other fins are pale. The main morphometric and meristic characters are presented in Table 1. 
Table 1. - Comparison of morphometric, meristic data and respective body proportions for specimens of $C$. regalis.

\begin{tabular}{|c|c|c|}
\hline Cynoscion regalis & CFM-IEOMA-6020 to $6032(\mathrm{~N}=13)$ & McEachran and Fechhelm 2005 \\
\hline Total Length (mm) & $276-330$ & - \\
\hline Standard length (mm) & $234-285$ & - \\
\hline \multicolumn{3}{|l|}{ As $\%$ SL } \\
\hline Head length & $27.1-28$ & $29-32$ \\
\hline Eye diameter & $5-6$ & $6-7$ \\
\hline Preorbital length & $5.9-7.4$ & $7-8$ \\
\hline Postorbital length & $15.8-16.5$ & - \\
\hline Interorbital length & $6.1-7.3$ & $5-6$ \\
\hline Maxillary length & $10.7-12.2$ & $13-14$ \\
\hline Predorsal length & $30.8-34.5$ & - \\
\hline Dorsal base length & $50.2-56.0$ & - \\
\hline Preanal length & 68.4-73.3 & - \\
\hline Anal base length & $9.7-11.8$ & - \\
\hline Pectoral length & $15.4-16.9$ & $13-15$ \\
\hline Pelvic length & $14.3-16.5$ & - \\
\hline Prepelvic length & $27.1-29.5$ & - \\
\hline Prepectoral length & $24.2-27.6$ & - \\
\hline Body depth & $24.2-28.3$ & $24-25$ \\
\hline \multicolumn{3}{|l|}{ Meristic features } \\
\hline Dorsal fin rays & $\mathrm{X}+\mathrm{I}+26-29$ & $\mathrm{X}+\mathrm{I}+24-29$ \\
\hline Anal fin rays & II+11-12 & II+10-13 \\
\hline Ventral fin rays & $\mathrm{I}+5$ & - \\
\hline Pectoral fin rays & $18-20$ & $18-19$ \\
\hline Pored scales lateral line & $54-59$ & - \\
\hline Branchiostegal rays & 7 & - \\
\hline Gill rakers & $5-6+1+10-11$ & $14-20$ \\
\hline
\end{tabular}

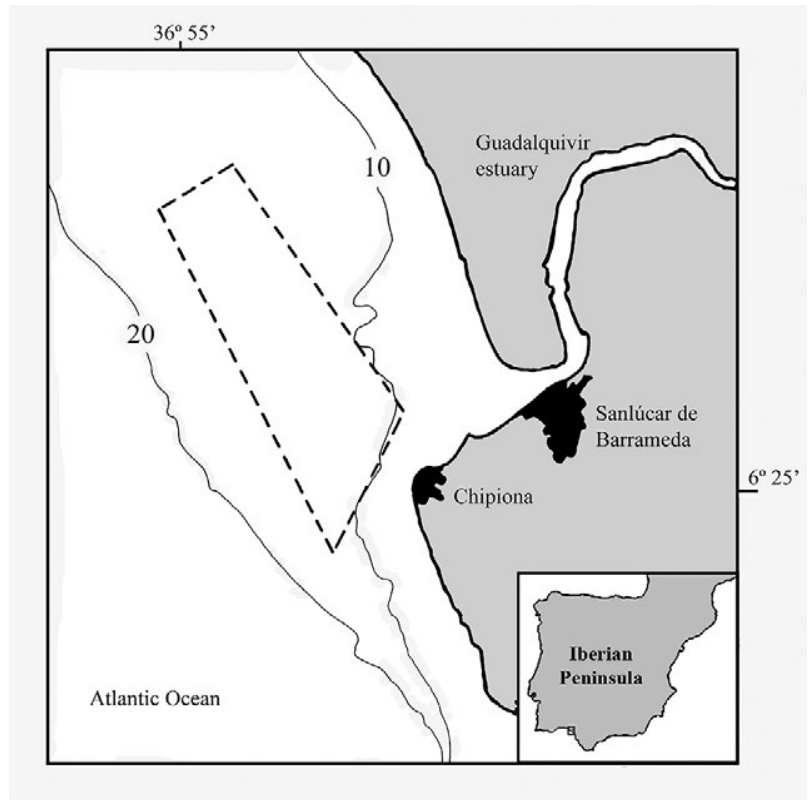

Fig. 2. - Map showing the main distribution area, framed by dashed line, of C. regalis in the Gulf of Cádiz based on fisheries data.

\section{Native distribution}

They are found on the Atlantic coast of North America from Nova Scotia to south Florida and on the western coast of Florida (uncommon) (McEachran and Fechhelm 2005), but they are most abundant off the coasts from North Carolina to New York (LowerreBarbieri 1996).

\section{Exotic distribution}

A juvenile specimen of $C$. regalis of $98 \mathrm{~mm} \mathrm{TL}$ was captured on 24 September 2009 by fyke net in the Schelde Estuary (Belgium) and the identification was confirmed by DNA analysis and published in Dutch in a local sport fishing magazine (Agentschap voor Natuuren Bos 2011). Recently this species was also caught in Portugal, in the Sado estuary (Béarez et al. 2016). In the Gulf of Cádiz, this species has been found between the cities of Cádiz and Ayamonte, although most catches come from the Guadalquivir estuary, mainly over muddy bottoms, close to the fishing villages of Chipiona and Sanlúcar de Barrameda (Fig. 2).

\section{Molecular identification}

The three 16S sequences of 611 bp obtained (GenBank accession numbers KX879594, KX879595 and KX879596) have the same haplotype as well as the three Cox 1 sequences of 660 bp (GenBank accession numbers KX879597, KX879598 and KX879599).

In the obtained trees, the sequences of studied specimens cluster in strong supported clades with one sequence of $16 \mathrm{~S}$ of $C$. regalis (Fig. 3) and eight sequences of Cox 1 of $C$. regalis (Fig. 4), and in both cases are clearly separated from the closely related congeneric species Cynoscion arenarius Ginsburg, 1930.

\section{Fishery and abundance}

This species has been caught sporadically since at least 2011, with regular catches since November 2015 and declared catches since February 2016 (Table 2) due to initial misidentification as A. regius. As misidentification continues among fishermen and fish market operators due to morphological similarities with $A$. regius, catches are likely to be greater than the declared values shown in Table 2 . Weakfish is not a target species, being mainly caught by gillnets of 60 $70 \mathrm{~mm}$ mesh size directed to Merluccius merluccius (Linnaeus, 1758) and Pagellus sp. and secondarily by bottom trawl, mainly over muddy bottoms. Declared 


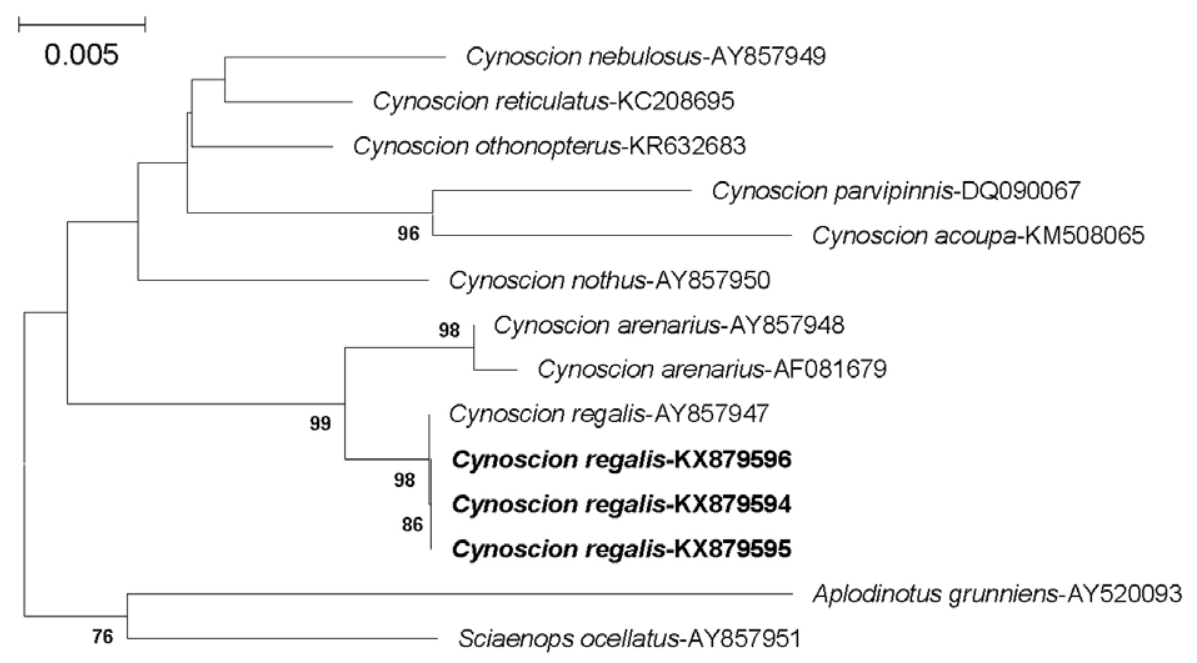

Fig. 3. - Topology of Neighbour-joining tree based on 611 bp of the $16 \mathrm{~S}$ gene sequences, showing inferred phylogenetic relationships within the genus Cynoscion with Aplodinotus grunniens and Sciaenops ocellatus as outgroups. Numbers close to nodes indicate bootstrap support (only values above $50 \%$ shown). GenBank accession numbers are shown after name of species.

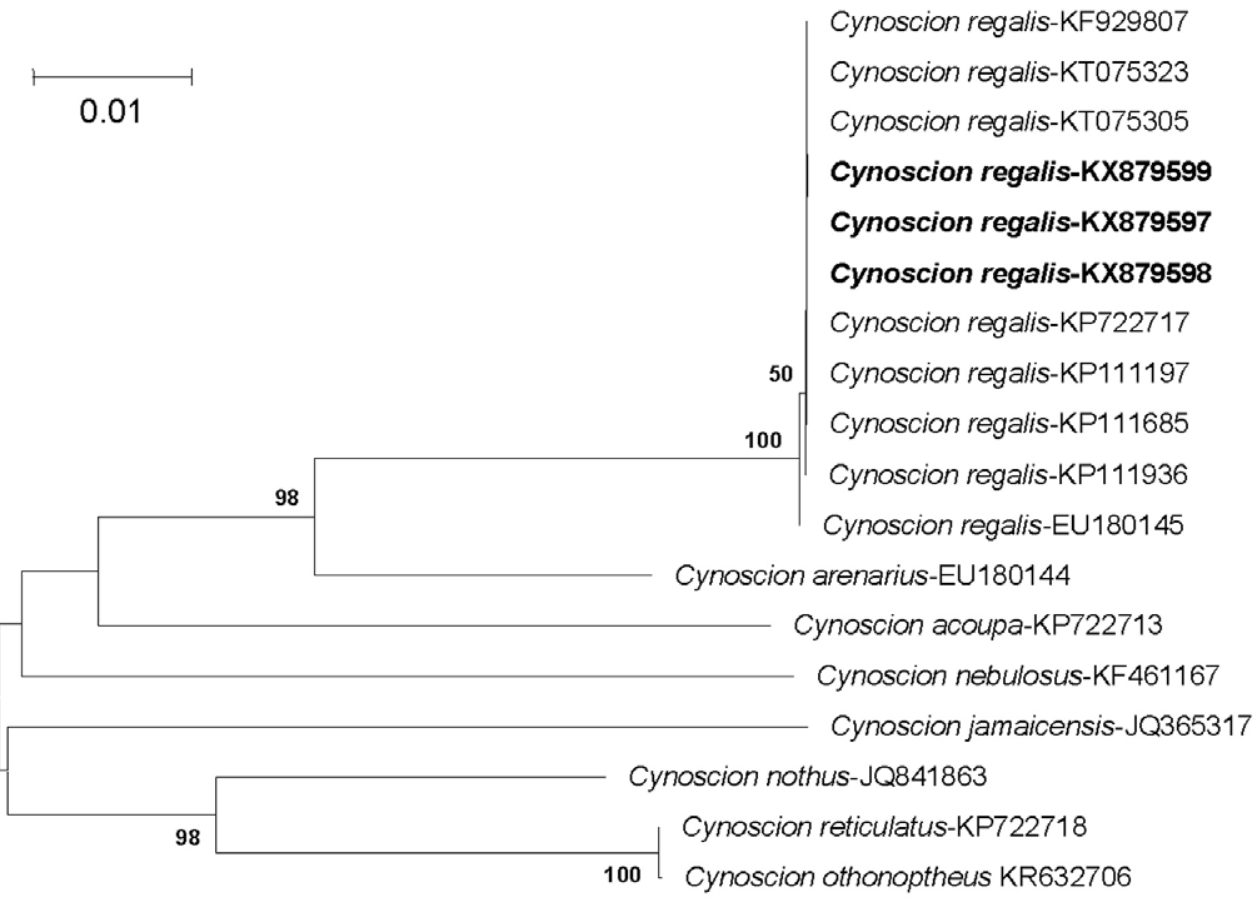

Fig. 4. - Topology of neighbour-joining tree based on $660 \mathrm{bp}$ of the Cox 1 gene sequences, showing inferred phylogenetic relationships within the genus Cynoscion. Numbers close to nodes indicate bootstrap support (only values above 50\% shown). GenBank accession numbers are shown after name of species.

Table 2. - Declared landings (in $\mathrm{kg}$ ) of C. regalis per month in ports of the Gulf of Cádiz in 2016.

\begin{tabular}{lccccc}
\hline Month & Chipiona & Sanlúcar & Rota & Puerto Sta. María & Weight \\
\hline February & 489.05 & 66.85 & 8.90 & - & 564.80 \\
March & 516.25 & 120.40 & 31.90 & 11.88 & 680.43 \\
April & 17.95 & - & 1.70 & 10.56 & 30.21 \\
Total & 1023 & 187 & 43 & 22 & 1275 \\
\hline
\end{tabular}

catches by month ranged from $30 \mathrm{~kg}$ in April to 680 $\mathrm{kg}$ in March. Habitual sizes ranged from about 25 to $35 \mathrm{~cm}$ TL, but specimens up to $50 \mathrm{~cm}$ TL were also caught.
Fishermen have no concern about this new species since no evidence of negative effects have been reported to date. Weakfish is being marketed locally as A. regius although dockside prices are slightly lower than those of $A$. regius.

\section{DISCUSSION}

The morphological measurements and meristic counts of the examined specimens identify the species as $C$. regalis, a finding which is also strongly supported by the molecular identification. 
The presence of scales at the base of the soft dorsal and anal fins, the colouration (mainly the colour and arrangement of the spots; Fig. 1), biometrics and meristic counts distinguish this species from other sciaenid species. Slight differences found in some biometrics (Table 1) could be due to the lower number of individuals or incomplete size range reported in the literature.

Acosta et al. (2013) reported one specimen of the congeneric $C$. nebulosus in the same area, near the Guadalquivir River estuary (southern Spain). However, a detailed revision of this manuscript showed an incomplete description of the specimen and, finally, an erroneous identification. In their description, the authors omitted an important distinctive character of the species. The presence/absence of scales at the base of soft dorsal and anal fins is a diagnostic character which distinguishes $C$. nebulosus (absence) from the similar C. regalis (presence) (Chao 2002a, b, Lassuy 1983). Although Acosta et al. (2013) reported the presence of spots on the caudal and dorsal fins characteristic of C. nebulosus, this aspect is not visible in the attached figure. C. nebulosus has distinct spots, comparatively fewer and bigger than those in $C$. regalis, and randomly scattered, whereas in $C$. regalis they form oblique and undulating lines (Chao 2002a, b). However, the figure of Acosta et al. (2013) shows a distribution pattern of spots typical of $C$. regalis. Moreover, the reported ten gill rakers count on the lower limb of the gill arch and the pectoral fin slightly longer than the pelvic fin also agree with the description of $C$. regalis, whereas $C$. nebulosus has 6-9 gill rakers on the lower limb of the gill arch and its pectoral fin is shorter than the pelvic fin (Lassuy 1983, Chao 2002a, b).

Molecular identification (16S and Cox1 genes) confirms the previous morphological identification of these specimens as $C$. regalis. The $16 \mathrm{~S}$ sequences obtained for the three specimens (Fig. 3) present the same haplotype, which fits $100 \%$ with the sequence of $C$. regalis deposited in GenBank under the accession number AY857947 and also $100 \%$ with a shorter sequence of $C$. regalis (390 bp) deposited in GenBank under the accession number EF095595, obtained in the context of a phylogenetic study of the percoid family Gerreidae (Chen et al. 2007).

In the case of the Cox1 sequences (Fig. 4), the three specimens also have the same haplotype, which fits $100 \%$ with four sequences of $C$. regalis deposited in GenBank under the accession numbers KT075323, KT075305, KF929807 and KP722717, belonging to different specimens collected in the US Atlantic waters, and also $100 \%$ with three sequences (KP111936, KP111685, KP111197) identified as Actinopterygii environmental samples of eggs attributed through barcoding to $C$. regalis in a study integrating DNA barcoding of fish eggs into ichthyoplankton monitoring programmes (Lewis et al. 2016). In GenBank there is only one more Cox1 sequence, identified as belonging to $C$. regalis (EU180145), which differs in just one mutation from the other seven (GenBank) and three (present study) sequences. This sequence belongs to specimens collected in Delaware (North Carolina) by Seyoum et al. (2013).
After the re-examination of the Acosta et al. (2013) manuscript, we conclude that $C$. nebulosus reported by these authors is a misidentification of $C$. regalis. Thus, this is the only introduced sciaenid species reported until now in the Gulf of Cádiz. The presence of $C$. regalis in the Gulf of Cádiz confirms its presence in Atlantic European waters.

Fishes are one of the largest contributors to the total number of non-indigenous species documented in European seas, accounting for $16.8 \%$ of the 879 multicellular non-indigenous species reported by Galil et al. (2014). However, most of these fish species are found in the Mediterranean, introduced via the Strait of Gibraltar (Atlantic species) and the Suez Canal (Lessepsian species) (Oral 2010). In the Atlantic European waters, including the Gulf of Cádiz, the most frequent case is the arrival of southern species by natural displacement due to global warming and changes in the oceanic conditions (Farias et al. 2012, Bañón et al. 2014). In both the Mediterranean (excluding Lessepsian species) and the Atlantic, only a few cases of rare fish species introduced from large distances are documented, such as the South American fish Pinguipes brasilianus Cuvier, 1829 in the Mediterranean (Orsi-Relini 2002) and the aforementioned $M$. undulatus in the Atlantic.

As in most cases of marine alien species, the introduction vector cannot be clearly identified. $C$. regalis is highly dependent on estuaries for food, shelter and spawning (Mercer 1989), so it is very unlikely that this species would have swam across the Atlantic Ocean to Spain. However, we cannot rule out this possibility.

Among the anthropogenic pathways of introduction, fishes have been undersampled in ballast water studies and the role of ballast transport in promoting fish invasions has probably been underestimated (Wonham et al. 2000). There are two major ports near the Guadalquivir estuary: the American naval station in Rota, located $20 \mathrm{~km}$ from Chipiona, and Sanlúcar de Barrameda, where most of the weakfish is caught. The station has a seaport and provides support to US and NATO ships, and not only military ships. In addition, the port of Cádiz, located some $25 \mathrm{~km}$ from Chipiona, features four commercial docks plus a shipyard that repairs ships from all over the world. To support this theory on the introduction of weakfish, some marine organisms are believed to have been introduced through ship ballast water in the Gulf of Cádiz (Cuesta et al. 2004, Chicharo et al. 2009) and the occurrence of the other European alien sciaenid M. undulatus, reported in Belgian waters, is likely to be due to transportation in ship ballast water (Stevens et al. 2004) as well.

Aquaculture is the other main vector of introduction of alien species and is the reported pathway of the Atlantic American scianid Sciaenops ocellatus (Linnaeus, 1766) on the western Taiwanese coast (Liao et al. 2010). However, as far as we know, the culture of weakfish is only in initial phases at global level, and there is no culture of this species in Spanish waters. Other possibilities of its introduction are very unlikely and were not taken into account. Therefore, as there is no culture data available, introduction by ballast water seems to be the most plausible introduction pathway. 
All data suggest that weakfish has survived well and has successfully established populations in the Guadalquivir estuary. The species has been present in the area for at least the last five years. It is very abundant and now forms part of the bycatch of coastal fishers, with declared catches of more than one tonne during three months (Table 2). The population is composed of different year classes and most records are larger than the estimated mean length at first maturity, established at age 1 and $164 \mathrm{~mm}$ TL for males and $170 \mathrm{~mm}$ TL for females (Lowerre-Barbieri et al. 1996), so they would be able to spawn.

Introduction and spreading of alien species are considered one of the main threats to biodiversity. Invasive species alter ecosystems, displace native species, change community structures and food webs, and alter fundamental processes, such as nutrient cycling and sedimentation (Molnar et al. 2008). In the case of fish species, decline of commercial stocks due to direct predation or competition for resources (food or space) is the presumed mechanism of negative impact (Katsanevakis et al. 2014). Therefore, the impact of $C$. regalis in the local ecosystem should be studied in detail as soon as possible.

\section{ACKNOWLEDGEMENTS}

We are deeply grateful to Declan Quigley (SeaFisheries Protection Authority), Maarten Stevens (Research Institute for Nature and Forest) and Douglas Herdson (Marine Fish Information Services) for the information of alien sciaenids present in the Atlantic European waters. Thanks are also due to Cristóbal Lobato (Agencia de Gestión Agraria y Pesquera de Andalucía) for his valuable work assisting fish market operators and fishermen to correctly identify weakfish from other sciaenids as well as gathering field information on landings and sizes. Thanks to Jacob Krause and Jeffrey A. Buckle (Center for Marine Sciences and Technology of the North Carolina State University) for their help during the very first stages of this study, when we were still trying to identify the species and for the information on weakfish life history. Thanks to Manuel Mellado (owner of fishing vessel "Sonia Primero") for providing the GPS point positions for drawing the map in Figure 2. Finally, we thank the fishmonger Manuel Morgado for providing us with the specimens of weakfish studied in the present work and Carlos Sánchez Nieto for his assistance in the laboratory work.

\section{REFERENCES}

Acosta J.J., Canoura J., Juárez, A. 2013. First record of Cynoscion nebulosus in the Spanish waters of the Gulf of Cadiz (ICES Division IXa South). Mar. Biodiv. Rec. 6: 1-3. http://dx.doi.org/10.1017/S1755267213000870

Agentschap voor Natuuren Bos. 2011. DNA ontmaskert de verdachte. Vislijn - Infoblad voor de openbare visserij in Vlaanderen. Jaargang 2011, p. 28.

Bañón R., Arronte J.C., Barros-García D., et al. 2013. Taxonomic study of Bathygadidae fishes (Gadiformes) from Atlantic Spanish waters combining morphological and molecular approaches. Zootaxa 3746: 552-566.

http://dx.doi.org/10.11646/zootaxa.3746.4.3

Bañón R., Barros-García D., Mucientes G., et al. 2014. Northern- most records of Pagrus auriga (Sparidae) and Pomadasys incisus (Haemulidae) in the eastern Atlantic. Acta Ichthiol. Piscat. 44: 323-327. http://dx.doi.org/10.3750/AIP2014.44.4.07

Bariche M., Torres M., Smith C., et al. 2015. Red Sea fishes in the Mediterranean Sea: a preliminary investigation of a biological invasion using DNA barcoding. J. Biogeogr. 42: 2363-2373. http://dx.doi.org/10.1111/jbi.12595

Béarez P., Gabriel S., Dettai A. 2016. Unambiguous identification of the non-indigenous species Cynoscion regalis (Sciaenidae) from Portugal. Cybium 40: 245-248.

Casatti L. 2002. Petilipinnis, a new genus for Corvina grunniens Schomburgk, 1843 (Perciformes, Sciaenidae) from the Amazon and Essequibo river basins and redescription of Petilipinnis grunniens. Papêpis Avulsos Zool. 42: 169-181. http://dx.doi.org/10.1590/S0031-10492002000700001

Chao N.L. 2002a. Taxonomy of the seatrout, genus Cynoscion (Pisces, Sciaenidae), with artificial keys to the species. In: Bortone S.A. (ed), Biology of the spotted seatrout. CRC Marine Biology Series, Boca Raton, pp. 5-15. http://dx.doi.org/10.1201/9781420040791.ch2

Chao N.L. 2002b. Scianidae. Croakers. In: Carpenter K.E. (ed.), FAO species identification guide for fishery purposes. The living marine resources of the Western Central Atlantic, Bony fishes part 2 (Opistognathidae to Molidae), sea turtles and marine mammals, Vol. 3. FAO, Rome, pp. 1583-1653.

Chen W.J., Ruiz-Carus R., Ortis G. 2007. Relationships among four genera of mojarras (Teleostei: Perciformes: Gerreidae) from the western Atlantic and their tentative placement among percomorph fishes. J. Fish Biol. 79: 202-218. http://dx.doi.org/10.1111/j.1095-8649.2007.01395.x

Chicharo M.A., Leitao T., Range P., et al. 2009. Alien species in the Guadiana Estuary (SE-Portugal/SW-Spain): Blackfordia virginica (Cnidaria, Hydrozoa) and Palaemon macrodactylus (Crustacea, Decapoda): potential impacts and mitigation measures. Aquat. Inv. 4: 501-506. http://dx.doi.org/10.3391/ai.2009.4.3.11

Crandall K.A., Fitzpatrick J.F.J. 1996. Crayfish molecular systematics: using a combination of procedures to estimate phylogeny. Syst. Biol. 45: 1-26. http://dx.doi.org/10.1093/sysbio/45.1.1

Criado-Aldeanueva F., García-Lafuente J., Vargas J.M., et al. 2006. Distribution and circulation of water masses in the Gulf of Cadiz from in situ observations. Deep-Sea Res. 53: 1144-1160. http://dx.doi.org/10.1016/j.dsr2.2006.04.012

Cuesta J.A., González-Ortegón E., Drake P., et al. 2004. First record of Palaemon macrodactylus Rathbun, 1902 (Decapoda, Caridea, Palaemonidae) from European waters. Crustaceana 77: 377-380. http://dx.doi.org/10.1163/1568540041181466

Estoup A., Largiader C.R., Perrot E., et al. 1996. Rapid one-tube DNA extraction for reliable PCR detection of fish polymorphic markers and transgenes. Mol. Mar. Biol. Biotec. 5: 295-298.

Farias C., González-García E., Gil J., et al. 2012. New records of rare fish species for the Gulf of Cádiz. ISMS12 International Symposium in Marine Sciences, (Poster).Cadiz, Spain, 24-26 Enero 2012.

Galil B.S., Marchini A., Occhipinti-Ambrogi A., et al. 2014. International arrivals: widespread bioinvasions in European Seas. Ethol. Ecol. Evol. 26: 152-171.

http://dx.doi.org/10.1080/03949370.2014.89765

Hulme P.E., Bacher S., Kenis M., et al. 2008. Grasping at the routes of biological invasions: a framework for integrating pathways into policy. J. Appl. Ecol. 45: 403-414. http://dx.doi.org/10.1111/j.1365-2664.2007.01442.x

Katsanevakis S., Wallentinus I., Zenetos A., et al. 2014. Impacts of invasive alien marine species on ecosystem services and biodiversity: a pan-European review. Aquat. Inv. 9: 391-423. http://dx.doi.org/10.3391/ai.2014.9.4.01

Lassuy D.R. 1983. Species profiles: 1ife histories and environmental requirements (Gulf of Mexico)-spotted seatrout. U.S. Fish and Wild-1ife Service, Division of Biological Services. FWS/ OBS-82111.4.U.S. Army Corps of Engineers, TR EL-82-4. 14 pp.

Lewis L.A., Richardson D.E., Zakharov E.V., et al. 2016. Integrating DNA barcoding of fish eggs into ichthyoplankton monitoring programs. Fish. Bull. 114: 153-165. http://dx.doi.org/10.7755/FB.114.2.3

Liao Y., Chen L., Shao K. 2010. The predatory Atlantic red drum, Sciaenops ocellatus, has invaded the western Taiwanese coast 
in the Indo-West Pacific. Biol Invasions 12: 1961-1965. http://dx.doi.org/10.1007/s10530-009-9642-x

Lo P.C., Liu S.H., Chao N.L., et al. 2015. A multi-gene dataset reveals a tropical New World origin and Early Miocene diversification of croakers (Perciformes: Sciaenidae). Mol. Phylogenet. Evol. 88: 132-143. http://dx.doi.org/10.1016/j.ympev.2015.03.025

Lloris D. 2015. Ictiofauna marina. Ed. Omega, Barcelona, 680 pp.

Lowerre-Barbieri S.K., Chittenden M.E., Barbieri L.R. 1996. The multiple spawning pattern of weakfish in the Chesapeake Bay and Middle Atlantic Bight. J. Fish Biol. 48: 1139-1163. http://dx.doi.org/10.1111/j.1095-8649.1996 tb01811x

McEachran J.D., Fechhelm J.D. 2005. Fishes of the Gulf of Mexico, Scorpaeniformes to Tetraodontiformes, Vol. 2. Univ. Texas Press, Austin, 1014 pp.

Mercer L.P. 1989. Species profiles: 1ife histories and environmental requirements of coastal fishes and invertebrates (Mid-Atlantic)weakfish. U.S. Fish Wildl. Serv. Biol. Rep. 82(11.109). U. S. Army Corps of Engineers, TR EL-82-4.17 pp.

Molnar J.L., Gamboa R.L., Revenga C., et al. 2008. Assessing the global threat of invasive species to marine biodiversity. Front. Ecol. Environ. 6: 458-492. http://dx.doi.org/10.1890/070064

Nelson J.S. 2006. Fishes of the World, 4th ed. John Wiley and Sons, New York, $601 \mathrm{pp}$.

Oral M. 2010. Alien fish species in the Mediterranean/Black Sea Basin. J. Black Sea/ Mediterranean Environment 16: 87-132.

Orsi-Relini L. 2002. Occurrence of the South-American fish Pinguipes brasilianus in the Mediterranean. Cybium 26: 147-149.

Quéro J.C., Porche P., Vayne, J.J. 2003. Guide des poissons de l'Atlantique européen. Delachaux and Niestlé, Paris, $465 \mathrm{pp}$.

Schubart C.D., Cuesta J.A., Felder D.L. 2002. Glyptograpsidae, a new brachyuran family from Central America: larval and adult morphology, and a molecular phylogeny of the Grapsoidea. J. Crustac. Biol. 22: 28-44.

http://dx.doi.org/10.1651/0278-0372(2002)022[0028:GANBF F]2.0.CO;2

Schubart C.D., Huber M.G.J. 2006. Genetic comparisons of German populations of the stone crayfish, Austropotamobius torrentium (Crustacea: Astacidae). Bull. Fr. Pêche Piscic. 380-381: 1019-1028. http://dx.doi.org/10.1051/kmae:2006008

Seyoum S., Barthel B.L., Tringali M.D., et al. 2013. Phylogenetic relationships among four Western Atlantic Cynoscion. Gulf of Mexico Sci. 31: 40-49.

Silva L., Gil J., Sobrino I. 2002. Definition of fleet components in the Spanish artisanal fishery of the Gulf of Cadiz (SW Spain ICES division IXa). Fish. Res. 59: 117-128. http://dx.doi.org/10.1016/S0165-7836(01)00420-9

Stevens M., Rappé G., Maes J., et al. 2004. Micropogonias undulatus (L.), another exotic arrival in European waters. J. Fish Biol. 64: 1143-1146. http://dx.doi.org/10.1111/j.1095-8649.2004.00369.x

Tamura K., Stecher G., Peterson D., et al. 2013. MEGA6: Molecular Evolutionary Genetics Analysis version 6.0. Mol. Biol. Evol. 30: $2725-2729$. http://dx.doi.org/10.1093/molbev/mst197

Vergara-Chen C., Aguirre W.E., González-Wangüemert M., et al. 2009. A mitochondrial DNA based phylogeny of weakfish species of the Cynoscion group (Pisces: Sciaenidae). Mol. Phylogenet. Evol. 53: 602-607. http://dx.doi.org/10.1016/j.ympev. 2009.06.013

Wonham M.J., Carlton J.T., Ruiz G.M., et al. 2000. Fish and ships: relating dispersal frequency to success in biological invasions. Mar. Biol. 136: 1111-1121. http://dx.doi.org/10.1007/s002270000303 